\title{
Penerapan Model Pembelajaran Contextual Teaching and Learning (CTL) Dalam Meningkatan Hasil Belajar Menyimak Cerita Rakyat Pada Siswa Kelas V SDN Kraton Kabupaten Kediri
}

\author{
Suparmi \\ SDN Kraton Kecamatan Mojo Kabupaten Kediri, Indonesia \\ Email: suparmikhoiri@gmail.com
}

\begin{tabular}{l}
\hline Tersedia Online di \\
\hline http://www.jurnal.unublitar.ac.id/ \\
index.php/briliant
\end{tabular}

\begin{tabular}{l}
\hline Sejarah Artikel \\
\hline Diterima pada 31 Oktober 2019 \\
Disetujui pada 29 November \\
2019 \\
Dipublikasikan pada 30 \\
November 2019 Hal. $455-463$ \\
\hline
\end{tabular}

Kata Kunci:

$\overline{\text { Hasil Belajar Menyimak, }}$ Contxtual Teaching and Learning (CLT), Cerita Rakyat

\section{DOI:}

http://dx.doi.org/10.28926/briliant .v3i4.398

\begin{abstract}
Abstrak: Tujuan dari penelitian ini yaitu (1) Mengetahui penggunaan model pembelajaran CTL terharap peningkatan hasil belajar menyimak cerita rakyat pada siswa kelas V SDN Kraton Kabupaten Kediri. (2) Mengetahui penggunaan model pembelajaran CTL dalam meningkatan aktivitas belajar menyimak cerita rakyat pada siswa kelas $\mathrm{V}$ SDN Kraton Kabupaten Kediri. Penelitian ini merupakan penelitian tindakan kelas dengan menggunakan dua siklus. Berdasarkan hasil penelitian diketahui bahwa pada siklus I, persentase ketuntasan belajar siswa sebesar $75 \%$ dengan nilai rata-rata kelas 75 . Setelah dilaksanakan siklus II, nilai rata-rata kelas maningkat menjadi 83 dengan persentase ketuntasan belajar siswa sebesar 93,75\%. Sehingga dapat disimpulkan bahwa terdapat peningkatan nilai rata-rata kelas dari siklus I ke siklus II sebesar 8 dengan kenaikan persentase ketuntasan belajar klasikal sebesar $18,75 \%$. Hasil pengamatan aktivitas siswa menunjukkan jumlah rata-rata skor aktivitas belajar siswa pada siklus I yakni sebanyak 307 dengan persentase keaktifan
\end{abstract} belajar siswa sebesar 53,21\% dengan kriteria "Cukup". Aktivitas belajar siswa mengalami peningkatan pada pelaksanaan siklus II. Jumlah rata-rata skor aktivitas belajar siswa pada siklus II yakni sebanyak 423 dengan persentase keaktifan belajar siswa sebesar 73,44\% dengan kriteria "Baik".

\section{PENDAHULUAN}

Keterampilan berbahasa (language skills) meliputi empat keterampilan dasar, yaitu keterampilan menyimak (listening skills), keterampilan berbicara (speaking skills), keterampilan membaca (reading skills) dan keterampilan menulis (writing skills). Keempat keterampilan berbahasa tersebut memiliki hubungan yang sangat erat antara satu dan lainnya. Menurut Haryadi dan Zamzani (1996: 19) keterampilan menyimak merupakan kegiatan yang paling awal dilakukan oleh anak manusia bila dilihat dari proses pemerolehan bahasa. Sebelum anak dapat melakukan berbicara, membaca, apalagi menulis, kegiatan menyimaklah yang pertama kali dilakukan. Secara berturut-turut pemerolehan 
keterampilan berbahasa itu pada umumnya dimulai dari menyimak, berbicara, dan terakhir menulis.

Pengajaran bahasa lisan sering kita jumpai istilah mendengar, mendengarkan, dan menyimak. Ketiga istilah itu memang berkaitan dalam makna namun berbeda dalam arti. Dalam kamus besar Bahasa Indonesia pengertian istilah itu dijelaskan seperti berikut. Mendengar diartikan sebagai menangkap bunyi (suara) dengan telinga. Mendengarkan berarti mendengarkan sesuatu dengan sungguh-sungguh. Sedang menyimak berarti mendengarkan (memperhatikan) baik-baik apa yang diucapkan atau dibicarakan orang (Djago Tarigan, 2003: 25). Sedangkan menurut Kamidjan dan Suyono (2002) menyimak adalah suatu proses mendengarkan lambang-lambang bahasa lisan dengan sungguh-sungguh penuh perhatian, pemahaman, apresiatif yang dapat disertai dengan pemahaman makna komunikasi yang disampaikan secara nonverbal. Menurut Hunt (dalam Henry Guntur Tarigan, 2008: 59) ada empat fungsi utama menyimak, yaitu: (1) Memperoleh informasi yang berkaitan dengan profesi; (2) Membuat hubungan antarpribadi lebih efektif; (3) Mengumpulkan data agar dapat membuat keputusan yg masuk akal; (4) Agar dapat memberikan responsi yang tepat.

Dari hasil observasi lapangan yang dilakukan terhadap hasil belajar mata pelajaran Bahasa Indonesia materi menyimak cerita rakyat pada siswa kelas $\mathrm{V}$ SDN Kraton Kecamatan Mojo Kabupaten Kediri tahun pelajaran 2018/2019 diketahui bahwa terdapat 9 siswa $(56,3 \%)$ yang tuntas dan 7 siswa $(43,7 \%)$ tidak tuntas dari jumlah 16 siswa keseluruhan Dari dideskripsikan terrsebut menyatakan bahwa pembelajaran memiliki permasalahan yaitu adanya siswa yang mengalami kesulitan dalam menyimak cerita. Cerita rakyat juga didefinisikan sebagai kesusastraan dari rakyat, yang penyebarannya pada umumnya melalui tutur kata atau lisan (Danandjaja, 2007: 5). Hal ini terlihat dari siswa yang belum tepat dan masih kesulitan dalam menemukan unsur-unsur intrinsik dalam sebuah cerita seperti penokohan, tema, latar dan amanat. Selain itu, beberapa siswa terlihat kurang bersemangat dalam mengikuti pelajaran, ada juga yang justru asyik mengobrol dengan temannya bahkan malah menggambar pada saat pembelajaran berlangsung.

Contextual teaching and learning merupakan salah satu model pembelajaran inovatif, dimana model pembelajaran ini menekankan tentang situasi kontekstual yang perlu diangkat sebagai bahan dalam memberikan pelajaran (Muslich, 2007: 33). Pembelajaran Contextual Teaching and Learning (CTL) adalah konsep pembelajaran yang membantu guru mengaitkan materi yang diajarkan dengan situasi dunia nyata siswa dan mendorong siswa membuat hubungan antara pengetahuan yang dimilikinya dengan penerapannya dalam kehidupan mereka sehari-hari (H. Baharudin dan Esa Nur Wahyuni, 2009: 138). Pada dasarnya model pembelajaran Contextual Teaching and Learning (CTL) mempunyai beberapa prinsip pokok. Jika prinsip itu dilaksanakan maka dapat dijamin bahwa pembelajaran kontekstual yang dilaksanakan akan berhasil seutuhnya. Ada tujuh prinsip utama pembelajaran yang mendasari pendekatan pembelajaran Contextual Teaching and Learning (CTL) di kelas. Nuradi (2003: 31), mengemukakan sebagai berikut: (1) konstruktivisme (constructivism), (2) penemuan (inquiry), (3) bertanya (questioning), (4) komunitas belajar (learning community), (5) 
pemodelan (modeling), (6) refleksi (reflection), (7) penilaian yang sebenarnya (authentic assasement).

Model pembelajaran ini tepat jika diajarkan pada mata pelajaran bahasa Indonesia. Model pembelajaran ini memungkinkan guru mendesain pembelajaran dari bahan-bahan (data) yang kontekstual yang terjadi. Sebab, yang menjadi dasar pijak model pembelajaran ini adalah bagaimana siswa dapat mengalami makna belajar. Bagaimana makna belajar itu dapat dialami? Jawabannya sederhana, berangkatlah mengajarkan sesuatu pada mereka dari situasi konteks kehidupannya. Robert M. Gagne (Sagala, 2005: 17) menjelaskan bahwa belajar merupakan yang terjadi setelah belajar terus-menerus, bukan hanya disebabkan oleh proses pertumbuhan saja. Belajar terjadi apabila situasi stimulus bersama dengan isi ingatan mempengaruhi siswa sedemikian rupa, sehingga perbuatannya berubah dari waktu sebelum ke waktu setelah ia mengalami situasi tadi. Hasil belajar adalah kemampuan yang dimiliki siswa setelah ia menerima pengalaman belajarnya (Sudjana, 2001: 22).

\section{METODE}

Jenis Penelitian ini termasuk Penelitian Tindakan Kelas (PTK) atau Classroom Action Research (CAR) yang dilakukan secara kolaboratif, artinya penulis sebagai peneliti berkolaborasi atau bekerjasama dengan guru. Guru dan peneliti mendiskusikan permasalahan penelitian dan menentukan rencana tindakan. Penelitian juga dilakukan secara partisipatif, artinya peneliti dengan dibantu rekan sejawat secara langsung terlibat dalam penelitian. Pengumpulan data akan dilakukan dengan dua cara yaitu (1) tes; (2) observasi, sedangkan instrumen yang digunakan dalam penelitian ini meliputi: (1) tes; (2) lembar pengamatan.

\section{HASIL}

Untuk mengetahui tingkat kemampuan siswa dalam mengidentifikasi unsur cerita rakyat diberikanlah tes. Hasil tes tersebut pada siklus I adalah sebagai berikut.

\begin{tabular}{cccrr}
\hline No & Nilai & Kategori & Jumlah & \multicolumn{1}{c}{ Prosentase } \\
\hline 1 & $\geq 75$ & Tuntas & 12 siswa & $75 \%$ \\
\hline 2 & $<75$ & Tidak tuntas & 4 siswa & $25 \%$ \\
\hline & Jumlah & & 16 siswa & $100 \%$ \\
\hline
\end{tabular}

Tabel 1. Prosentase Ketuntasan Hasil Belajar Siklus I

Dari tabel 1 yang telah tersaji dapat dilihat bahwa 12 siswa atau $75 \%$ mengalami ketuntasan dengam $\mathrm{KKM} \geq 75$, sedangkan 4 siswa atau $25 \%$ siswa belum mencapai ketuntasan belajar pada kondisi siklus I. Ketuntasan secara klasikal pada siklus ini juga belum tercapai dari ketuntasan secara klasikal yaitu $85 \%$.

Untuk mendapatkan data aktivitas belajar siswa, digunakan teknik nontes yakni melalui pengamatan. Pengamatan dilakukan selama proses pembelajaran berlangsung. Aspek-aspek yang harus diamati dalam proses pembelajaran meliputi: (1) kesiapan siswa daam mengikuti pembelajaran (2) siswa memperhatikan penjelasan dari guru (3) keaktifan siswa dalam bertanya (4) keaktifan siswa dalam menjawab pertanyaan (5) ketertiban siswa dalam mengikuti 
peajaran dengan menggunakan model pembelajaran Contextual Teaching and Learning (CTL) (6) keaktifan siswa dalam kerja kelompok (7) membuat kesimpulan materi pembelajaran (8) menyampaikan hasil diskusi kelompok (9) mengerjakan soal evaluasi. Dari hasil observasi keseluruhan terhadap aktifitas siswa pada siklus I, maka diperoleh hasil sebagai berikut.

\begin{tabular}{|c|c|c|c|c|c|c|c|}
\hline \multirow{2}{*}{ No } & \multirow{2}{*}{ Indikator } & \multicolumn{3}{|c|}{ Pertemuan Pertama } & \multicolumn{3}{|c|}{ Pertemuan Kedua } \\
\hline & & $\mathrm{Jml}$ & $\mathrm{Rr}$ & $(\%)$ & $\mathrm{Jml}$ & $\mathrm{Rr}$ & $(\%)$ \\
\hline 1 & $\begin{array}{l}\text { Kesiapan siswa dalam } \\
\text { mengikuti pembelajaran }\end{array}$ & 36 & 2,25 & 56,25 & 46 & 2,88 & 71,88 \\
\hline 2 & $\begin{array}{l}\text { Siswa memperhatikan } \\
\text { penjelasan dari guru }\end{array}$ & 38 & 2,38 & 59,38 & 41 & 2,56 & 64,06 \\
\hline 3 & $\begin{array}{l}\text { Keaktifan siswa dalam } \\
\text { bertanya }\end{array}$ & 35 & 2,19 & 54,69 & 36 & 2,25 & 56,25 \\
\hline 4 & $\begin{array}{l}\text { Keaktifan siswa } \\
\text { menjawab pertanyaan }\end{array}$ & 25 & 1,56 & 39,06 & 41 & 2,56 & 64,06 \\
\hline 5 & $\begin{array}{lr}\text { Ketertiban siswa } & \text { dalam } \\
\text { mengikuti pelajaran } & \text { dengan } \\
\text { menggunakan } & \text { model } \\
\text { pembelajaran } & \text { Contextual } \\
\text { Teaching and Learning (CTL) }\end{array}$ & 28 & 1,75 & 43,75 & 41 & 2,56 & 64,06 \\
\hline 6 & $\begin{array}{l}\text { Keaktifan siswa dalam kerja } \\
\text { kelompok }\end{array}$ & 25 & 1,56 & 39,06 & 38 & 2,38 & 59,38 \\
\hline 7 & $\begin{array}{l}\text { Membuat kesimpulan materi } \\
\text { pembelajaran }\end{array}$ & 22 & 1,38 & 34,38 & 34 & 2,13 & 53,13 \\
\hline 8 & $\begin{array}{l}\text { Menyampaikan hasil diskusi } \\
\text { kelompok }\end{array}$ & 25 & 1,56 & 39,06 & 31 & 1,94 & 48,44 \\
\hline 9 & Mengerjakan soal evaluasi & 30 & 1,88 & 46,88 & 41 & 2,56 & 64,06 \\
\hline \multicolumn{2}{|c|}{ Jumlah } & \multicolumn{3}{|c|}{264} & \multicolumn{3}{|c|}{349} \\
\hline \multicolumn{2}{|c|}{ Persentase } & \multicolumn{3}{|c|}{$45,83 \%$} & \multicolumn{3}{|c|}{$60,59 \%$} \\
\hline \multicolumn{2}{|c|}{ Kategori } & \multicolumn{3}{|c|}{ Cukup } & \multicolumn{3}{|c|}{ Cukup } \\
\hline
\end{tabular}

Tabel 2. Hasil Observasi Aktifitas Siswa Siklus I

Sesuai tabel 2 bahwa observasi terhadap aktifitas siswa pada pertemuan pertama diperoleh 264 poin dengan presentase 45,83\% masuk pada kategori "Cukup". Sedangkan pada pertemuan kedua diperoleh nilai 349 poin dengan presentase 60,59\% masuk kategori "Cukup".

Dari hasil observasi keseluruhan terhadap aktifitas siswa pada siklus I, maka diperoleh hasil sebagai berikut.

\begin{tabular}{lclcc}
\hline \multicolumn{2}{c}{ Pertemuan Pertama } & \multicolumn{2}{c}{ Pertemuan Kedua } & Rata-rata Siklus I \\
\hline Jumlah & 264 & Jumlah & 349 & 307 \\
\hline Persentase & $45,83 \%$ & Persentase & $60,59 \%$ & $53,21 \%$ \\
\hline Kategori & Cukup & Kategori & Cukup & Cukup \\
\hline
\end{tabular}

Berdasarkan tabel 3 di atas dapat dilihat bahwa jumlah skor yang diperoleh seluruh siswa kelas V SDN Kraton pada pertemuan pertama dan kedua pada siklus I adalah 307 atau 53,21\% dengan kategori "Cukup". Artinya tingkat keaktifan siswa pada siklus I apabila melihat tabel kriteria keaktifan siswa 
sebelumnya belum berhasil, karena keberhasilan aktifitas siswa apabila presentase keaktifan telah mencapai 65-84\% dengan kategori "Baik". Ketidakberhasilan ini diakibatkan oleh kurangnya skor pada 5 indikator, yakni tingkat keaktifan siswa menjawab pertanyaan, ketertiban siswa dalam mengikuti pelajaran, membuat kesimpulan materi pembelajaran, keaktifan siswa dalam kerja kelompok, dan menyampaikan hasil diskusi. Dari kelima indikator yang kurang ini maka diperlukan perbaikan pada siklus II. Ketidakberhasilan ini diakibatkan oleh kurangnya skor pada 5 indikator, yakni tingkat keaktifan siswa menjawab pertanyaan, ketertiban siswa dalam mengikuti pelajaran, membuat kesimpulan materi pembelajaran, keaktifan siswa dalam kerja kelompok, dan menyampaikan hasil diskusi.

Rekapitulasi mengenai hasil belajar Mengidentifikasi unsur cerita rakyat yang didengar siswa pada siklus II dapat dilihat pada tabel 4 berikut ini.

\begin{tabular}{cccrr}
\hline No & Nilai & Kategori & Jumlah & Prosentase \\
\hline 1 & $\geq 75$ & Tuntas & 15 siswa & $93,75 \%$ \\
\hline 2 & $<75$ & Tidak tuntas & 1 siswa & $6,25 \%$ \\
\hline & Jumlah & & 16 siswa & $100 \%$ \\
\hline
\end{tabular}

Tabel 4. Prosentase Ketuntasan Hasil Belajar Siklus II

Pada tabel 4 menunjukkan ketutasan belajar klasikal siswa pada siklus II terdapat 15 siswa atau $93,75 \%$ yang tuntas belajar. Siswa yang belum tuntas belajar sebanyak 1 siswa atau 6,25\%. Berdasarkan perolehan tersebut, pembelajaran Mengidentifikasi unsur cerita rakyat yang didengar pada siklus II dapat dikatakan berhasil. Hal tersebut dikarenakan pembelajaran pada siklus II telah memenuhi kriteria yang ditentukan, yaitu persentase ketuntasan belajar klasikal sebesar $85 \%$.

Rekapitulasi data aktivitas belajar siswa pada siklus II dapat dibaca pada tabel 5 dan data selengkapnya dapat dilihat pada tabel di bawah ini.

\begin{tabular}{|c|c|c|c|c|c|c|c|}
\hline \multirow{2}{*}{ No } & \multirow{2}{*}{ Indikator } & \multicolumn{3}{|c|}{ Pertemuan Pertama } & \multicolumn{3}{|c|}{ Pertemuan Kedua } \\
\hline & & $\mathrm{Jml}$ & $\mathrm{Rr}$ & $(\%)$ & $\mathrm{Jml}$ & $\mathrm{Rr}$ & $(\%)$ \\
\hline 1 & $\begin{array}{l}\text { Kesiapan siswa dalam } \\
\text { mengikuti pembelajaran }\end{array}$ & 48 & 3,00 & 75,00 & 53 & 3,31 & 82,81 \\
\hline 2 & $\begin{array}{l}\text { Siswa memperhatikan } \\
\text { penjelasan dari guru }\end{array}$ & 44 & 2,75 & 68,75 & 47 & 2,94 & 73,44 \\
\hline 3 & 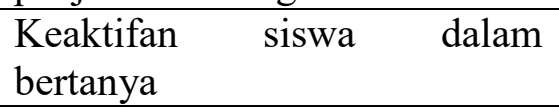 & 41 & 2,56 & 64,06 & 48 & 3,00 & 75,00 \\
\hline 4 & $\begin{array}{l}\text { Keaktifan siswa dalam } \\
\text { menjawab pertanyaan }\end{array}$ & 48 & 3,00 & 75,00 & 48 & 3,00 & 75,00 \\
\hline 5 & 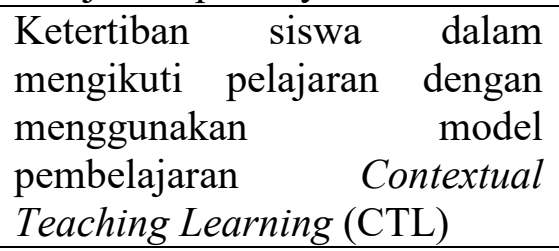 & 46 & 2,88 & 71,88 & 54 & 3,38 & 84,38 \\
\hline 6 & $\begin{array}{l}\text { Keaktifan siswa dalam kerja } \\
\text { kelompok }\end{array}$ & 47 & 2,94 & 73,44 & 52 & 3,25 & 81,25 \\
\hline 7 & $\begin{array}{l}\text { Membuat kesimpulan materi } \\
\text { pembelajaran }\end{array}$ & 43 & 2,69 & 67,19 & 48 & 3,00 & 75,00 \\
\hline 8 & $\begin{array}{l}\text { Menyampaikan hasil diskusi } \\
\text { kelompok }\end{array}$ & 38 & 2,38 & 59,38 & 44 & 2,75 & 68,75 \\
\hline
\end{tabular}




\begin{tabular}{|c|c|c|c|c|c|c|c|}
\hline 9 & Mengerjakan soal evaluasi & 48 & 3,00 & 75,00 & 49 & 3,06 & 76,56 \\
\hline \multicolumn{2}{|c|}{ Jumlah } & \multicolumn{3}{|c|}{403} & \multicolumn{3}{|c|}{443} \\
\hline \multicolumn{2}{|c|}{ Persentase } & \multicolumn{3}{|c|}{$69,97 \%$} & \multicolumn{3}{|c|}{$76,91 \%$} \\
\hline \multicolumn{2}{|c|}{ Kategori } & \multicolumn{3}{|c|}{ Baik } & \multicolumn{3}{|c|}{ Baik } \\
\hline
\end{tabular}

Tabel 5. Hasil Observasi Aktifitas Siswa Siklus II

Sesuai tabel 5 bahwa observasi terhadap aktifitas siswa pada pertemuan pertama diperoleh 403 poin dengan presentase $69,97 \%$ masuk pada kategori "Baik". Sedangkan pada pertemuan kedua diperoleh nilai 443 poin dengan presentase 76,91\% masuk kategori "Baik". Dari hasil observasi keseluruhan terhadap aktifitas siswa pada siklus II, maka diperoleh hasil sebagai berikut :

\begin{tabular}{|l|c|l|c|c|}
\hline \multicolumn{2}{|c|}{ Pertemuan Pertama } & \multicolumn{2}{c|}{ Pertemuan Kedua } & $\begin{array}{c}\text { Rata-rata Siklus } \\
\text { II }\end{array}$ \\
\hline Jumlah & 403 & Jumlah & 443 & 423 \\
\hline Persentase & $69,97 \%$ & Persentase & $76,91 \%$ & $73,44 \%$ \\
\hline Kategori & Baik & Kategori & Baik & Baik \\
\hline
\end{tabular}

Tabel 6. Rekapitulasi Observasi Aktfitas Siswa Siklus II

Tabel 6 menunjukkan hasil pengamatan aktivitas siswa pada siklus II. Siswa secara klasikal mendapat skor sebanyak 423 dan persentase keaktifan siswa sebesar 73,44\% dengan kriteria "Baik". Data tersebut diperoleh dari pengamatan yang dilakukan oleh teman sejawat pada pertemuan pertama dan kedua pada siklus II. Berdasarkan penghitungan terhadap aktfitas siswa pertemuan pertama dan kedua, dapat dikatakan bahwa pembelajaran mendengarkan isi cerita rakyat dengan model pembelajaran Contextual Teaching Learning (CTL) pada siklus II berhasil. Hal tersebut dapat dibaca dari hasil pengamatan aktivitas belajar siswa pada siklus II yang telah mencapai kriteria yang telah ditentukan. Persentase keaktifan siswa pada siklus II yakni sebesar 83,93\% dengan kategori "Baik" telah memenuhi kriteria keberhasilan yang ditentukan yakni dengan kriteria baik (65$84 \%)$.

Dengan hasil yang diperoleh, maka dikatakan bahwa setelah melakukan perbaikan-perbaikan selama tindakan pada siklus II, pembelajaran yang diterapkan berhasil. Keberhasilan ini didukung oleh peningkatan kinerja guru dalam memperhatikan karakteristik tiap-tiap siswa. Dengan memperhatikan karakteristik dan mempertimbangkan peran-peran yang harus dilaksanakan dalam melaksanakan pembelajaran Contextual Teaching Learning (CTL), memberikan hasil sesuai yang diharapkan.

\section{PEMBAHASAN}

Setelah siklus I selesai dilaksanakan, terdapat peningkatan pada nilai ratarata hasil belajar siswa. Pada pelaksanaan tes formatif siklus I diperoleh nilai ratarata kelas sebesar 75. Persentase ketuntasan belajar klasikal siswa pada siklus I sebesar $75 \%$. Persentase ketuntasan belajar klasikal siswa belum memenuhi kriteria ketuntasan belajar klasikal yaitu $85 \%$. Pembelajaran pada siklus I belum dapat dikatakan berhasil karena belum mencapai indikator keberhasilan yang ditentukan.

Pada siklus II terdapat peningkatan hasil belajar siswa diketahui dari nilai rata-rata sebesar 83 dengan persentase ketuntasan belajar klasikal sebesar 93,75\%. 
Peningkatan ini terjadi karena pada pelaksanaan pembelajaran siklus II siswa sudah mulai terbiasa dengan penggunaan model pembelajaran Contextual Teaching Learning (CTL) dalam pembelajaran Mengidentifikasi unsur cerita rakyat yang didengar dalam Bahasa Indonesia. Siswa sudah memperhatikan penjelasan guru dengan antusias. Disamping itu, siswa sudah mulai serius ketika melaksanakan kegiatan pembelajaran, siswa juga sudah tidak malu untuk bertanya dan mengungkapkan pendapatnya. Peningkatan hasil belajar Bahasa Indonesia materi Mengidentifikasi unsur cerita rakyat yang didengar secara keseluruhan mulai dari siklus I dan siklus II dapat dibaca pada tabel 7.

\begin{tabular}{cccrrrr}
\hline No & Nilai & Kategori & Siklus I & $\begin{array}{c}\text { Prosen } \\
\text { tase }\end{array}$ & Siklus II & $\begin{array}{c}\text { Prosen } \\
\text { tase }\end{array}$ \\
\hline 1 & $\geq 75$ & Tuntas & 12 siswa & $75 \%$ & 15 siswa & $93,75 \%$ \\
\hline 2 & $<75$ & Tidak tuntas & 4 siswa & $25 \%$ & 1 siswa & $6,25 \%$ \\
\hline & Jumlah & & 16 siswa & $100 \%$ & 16 siswa & $100 \%$ \\
\hline
\end{tabular}

Tabel 7. Perbandingan Peningkatan Hasil Belajar Siklus I dan II

Hasil belajar yang diperoleh pada siklus II dianggap memuaskan bagi peneliti. Hal tersebut dikarenakan hasil belajar yang diperoleh siswa telah mencapai kriteria keberhasilan yang telah ditentukan. Perolehan hasil belajar tersebut membuktikan bahwa pembelajaran pada siklus II berhasil.

Melalui proses pengamatan dapat diperoleh data mengenai aktivitas belajar siswa. Persentase aktivitas belajar siswa pada siklus I yaitu sebesar 53,21\% dengan kategori keaktifan siswa "Cukup". Hasil tersebut belum mencapai indikator keberhasilan yang ditentukan yaitu keaktifan siswa 65-84\% dengan kategori baik. Pada pelaksanaan pembelajaran siklus I siswa masih merasa malu untuk mengungkapkan pendapatnya maupun bertanya. Siswa lebih banyak duduk diam pada saat pembelajaran berlangsung. Terdapat beberapa siswa yang kurang memperhatikan penjelasan guru. Selain itu, siswa kurang serius ketika mengerjakan tugas. Pada pelaksanaan pembelajaran siklus II terjadi peningkatan aktivitas belajar siswa.

Pada siklus II persentase keaktifan belajar siswa meningkat menjadi 73,44\% dengan kategori keaktifan belajar "Baik". Artinya terjadi peningkatan persentase keaktifan belajar siswa sebesar 20,23\%. Pada pelaksanaan siklus II siswa sudah mulai tidak malu untuk bertanya dan mengemukakan pendapat. Perhatian siswa selama pelaksanaan siklus II juga mengalami peningkatan, siswa lebih tertarik dengan media audio dan audio visual yang ditampilkan oleh guru. Siswa tidak lagi berbicara sendiri pada saat pelaksanaan pembelajaran berlangsung sehingga suasana kelas lebih kondusif. Siswa ketika mengerjakan tugas tepat waktu dan penuh dengan tanggung jawab. Hal tersebut menunjukkan adanya peningkatan aktivitas belajar siswa pada siklus II.

Berdasarkan data yang diperoleh pada siklus II, dapat disimpulkan bahwa pembelajaran Bahasa Indoneisa materi Mengidentifikasi unsur cerita rakyat yang didengar dengan model pembelajaran Contextual Teaching Learning (CTL) pada siklus II berhasil. Hal tersebut dapat dilihat dari hasil pengamatan aktivitas belajar siswa pada siklus II yang telah mencapai kriteria yang telah ditetapkan. Persentase keaktifan siswa pada siklus II yakni sebesar $83,93 \%$ telah memenuhi kriteria keberhasilan yang ditentukan yakni 65 - 84\%. Data mengenai peningkatan aktivitas belajar siswa dalam penelitian ini dapat dibaca pada tabel 8 


\begin{tabular}{lclc}
\hline \multicolumn{2}{c}{ Siklus I } & \multicolumn{2}{c}{ Siklus II } \\
\hline Jumlah & 307 & Jumlah & 423 \\
\hline Persentase & $53,21 \%$ & Persentase & $73,44 \%$ \\
\hline Kategori & Cukup & Kategori & Baik \\
\hline & Tabel 8. Peningkatan Aktifitas Belajar Siswa Siklus I dan II
\end{tabular}

\section{KESIMPULAN}

Hasil penelitian menunjukkan bahwa penggunaan pendekatan Contextual Teaching and Learning (CTL) telah berhasil meningkatkan hasil belajar siswa pada pembelajaran Bahasa Indonesia materi menyimak cerita rakyat pada siswa kelas V SDN Kraton Kabupaten Kediri. Dari kedua siklus dapat diketahui terdapat peningkatan yang signifikan, yaitu: (1) Pada siklus I, nilai rata-rata kelas menjadi 75 dengan persentase ketuntasan belajar klasikal sebesar 75\%. Setelah dilaksanakan siklus II, nilai rata-rata kelas menjadi 83 dan persentase ketuntasan belajar klasikal menjadi 93,75\%. Sehingga dapat disimpulkan peningkatan nilai rata-rata kelas dari siklus I ke siklus II sebesar 8 dan kenaikan persentase ketuntasan belajar klasikal sebesar $18,75 \%$. Persentase ketuntasan belajar yang diperoleh pada siklus II sudah mencapai indikator keberhasilan yang telah ditentukan yaitu sebesar $85 \%$. Peningkatan hasil belajar tersebut membuktikan keberhasilan pembelajaran dengan menggunakan pendekatan Contextual Teaching and Learning (CTL). (2) Hasil pengamatan aktivitas belajar siswa dalam proses pembelajaran menunjukkan jumlah rata-rata skor aktivitas belajar siswa pada siklus I yakni sebanyak 307 dengan persentase keaktifan belajar siswa sebesar 53,21\% dengan kriteria "Cukup". Terdapat peningkatan aktivitas belajar siswa pada siklus II dengan Jumlah rata-rata skor sebanyak 423 dengan persentase keaktifan belajar siswa sebesar 73,44\% dengan kriteria "Baik".

\section{SARAN}

Penggunan model pembelajaran Contextual Teaching and Learning (CTL) dapat diterapkan oleh guru dalam mengajar meyimak cerita rakyat untuk meningkatkan hasil belajar siswa. Selain itu pembelajaran menggunakan pendekatan ini tidak hanya dapat diterapkan pada materi menyimak saja. Guru dapat menerapkannya pada materi lain sesuai kebutuhan.

\section{DAFTAR RUJUKAN}

Baharudin, H dan Esa Nur Wahyuni. 2009. Teori Belajar dan Pembelajaran. Jogjakarta: Ar-Ruzz Media.

Danandjaja, James. 2007. Folklor Indonesia, Ilmu Gosip, Dongeng, dan lain-lain. Jakarta: Grafiti.

Haryadi dan Zamzani. 1996. Peningkatan Ketrampilan Berbahasa Indonesia. Jakarta: Departemen Pendidikan dan Kebudayaan.

Muslich, Masnur. 2007. KTSP Pembelajaran Berbasis Kompetensi dan Kontekstual. Jakarta: Bumi Aksara.

Nurhadi, dkk. 2003. Mengapa CTL Menjadi Pilihan. Bandung: Remaja Rosdakarya.

Sagala, Saiful. 2005. Konsep dan Makna Pembelajaran. Bandung: Alfabeta.

Sudjana, Nana. 2001. Penilaian Hasil Proses Belajar Mengajar. Bandung: PT Remaja Rosdakarya. 
Tarigan, Djago. 2007. Pengembangan Ketrampilan Berbicara. Jakarta: Depdikbud.

Tarigan, Henry Guntur. 1986. Teknik Pengajaran Ketrampilan Berbahasa. Bandung: Angkasa. 